\title{
ANALYSIS OF AIR TRAFFIC IN EUROPEAN REGION
}

\author{
National Aviation University \\ Kosmonavta Komarova avenue 1, 03680, Kyiv, Ukraine \\ E-mails: ${ }^{1}$ luppo-ae@mail.ru; ${ }^{2}$ oks_glushko@mail.ru; ${ }^{3}$ dolmatova_darya@ukr.net
}

\begin{abstract}
Was provided analysis of current air traffic, considered possible developments in air traffic, studied long-term forecast of air traffic growth in European region.

Keywords: capacity, IFR flights, long-term forecast, sectors of European region.
\end{abstract}

\section{Introduction}

Air traffic - traffic created by the movement of aircraft. All aircraft in flight or operating on the maneuvering area of an aerodrome (ICAO...2007).

Every day, week, month, year a lot of people use air traffic for movements across the Earth. Such demand in air traffic transportations can cause extreme growth of air traffic, especially in areas of the Eastern Europe.

There are plenty of potentials for further growth of air traffic in Europe. But the demand is not homogenous and the traffic growth will not be uniform.

Our article presents the Long Term Forecast (LTF) of annual numbers of instrument flight rules (IFR) movements between 2014 and 2030. The long-term forecast is developed by growing baseline traffic using a model of economic and industry developments, taking into account factors related to passenger demand, economic growth, prices, air network structure and fleet composition.

Two key constraints are:

1) It is assumed that routing between airport pairs follows the same patterns observed in 2007. No calculations are made of the influence of future route networks, or of changes by aircraft operators in choice of route.

2) The forecast is constrained by annual airport capacities.

Four "scenarios" are used to capture the likely range of growth of flight movements.These are designed to describe four qualitatively different futures for the air traffic industry.

How might future demand look like?

The simple, smooth growth curves that are often seen in air traffic forecasts can encourage us to plan simplistic, one-size-fits-all solutions.
These curves lull us into believing that air traffic is a homogeneous mass swelling at 3-4\% per year, that just needs a firm hand to accommodate and manage its growth.

But air traffic demand is far from homogeneous, and its growth is far from uniform or guaranteed. Air traffic is composed of a number of market segments each having its specific patterns of operation and addressing differing needs of the demand for flights:

There are the traditional scheduled carriers, with their regular schedules carrying passengers and freight between major political and population centers.

The charter specialists, with high Summer peak passenger demand to specific holiday destinations often from airports with very limited scheduled traffic.

The low-cost carriers focused on leisure passengers, half eating into the existing markets, half building entirely new ones.

The business aviation at the other side of the spectrum operating business passenger services at very short notice on an extraordinary variety of routes, mostly short-haul and rarely competing directly with scheduled traffic.

The all cargo carriers often having regular schedules and networks, but operating at different times of day and to different airports than the scheduled passenger carriers.

The military, flying under civil or military control needing sometimes routes, but more usually volumes of airspace.

Then the rest, mostly general aviation.

The aggregate of traffic may be relevant to some challenges such as carbon dioxide $\mathrm{CO}_{2}$ emissions, but most air traffic demand is specific to a place and time, so each ATM challenge has a different composition and will evolve in a different way. 


\section{Four future scenarios which influence the air traffic growth}

Four scenarios are used in the LTF to capture the future of the air industry (EUROCONTROL...2008).

The four scenarios are:

Scenario A: Global Growth: Strong economic growth in an increasingly globalised economy, with technology used successfully to mitigate the effects of challenges such as environment and security.

Scenario B: Business as Usual: Moderate economic growth and little change from the status quo, that is, trends continue as currently observed.

Scenario C: Regulation \& Growth: Moderate economic growth, but with stronger regulation to address growing environmental challenges for aviation and for Europe more generally.

Scenario D: Fragmenting World: A World with increasing tensions between regions, with knock-on effects of weaker economies, reduced trade and less longhaul travel.

The most important elements which will influence the future air traffic forecast are:

GDP growth averages $2.2 \%$ year $( \pm 0.5$ p.p. depending on the scenario) for 2014-2030 in the European region.

Oil price is between $\$ 90$ and $\$ 180$ per barrel in 2030 (in 2008 US dollars). Shocks to the fuel price can appear in the short-term but dissipate in the longterm.

Aviation participates in the $\mathrm{CO}_{2}$ Emissions Trading Scheme from 2012. The allocations are fully auctioned by 2030 and the prices are $€ 25-€ 90$ per tonne $\mathrm{CO}_{2}$ (current contracts for 2012 are at around $€ 28$ ).

EU enlargement brings more economic opportunities for the countries as well as more travel options for their inhabitants. By 2030, all the Balkan States have integrated into the European Union, Turkey has joined in 2 of the 4 scenarios.
High-speed rail continues to develop and substitute for the air travel on shortdistances where it can reach comparable travel time and provide sufficient comfort. Close to 100 city-pairs are linked by high-speed rail in 2030 .

There are new types of aircraft in the fleet in 2030, which has on average 30-50 more seats per airframe than now; 300-900 very large aircraft with capacity over 500 passengers (A380 or similar) fly Europe.

\section{Forecast growth in IFR movements to 2030}

The results of the LTF are that there will be between 16.5 million and 22.1 million IFR flights in Europe in 2030. This is between 1.7 and 2.2 times the number seen in 2007. This doubling of traffic by 2030 means that each year on a typical day more than 1000 extra flights will need to be handled than in the year before. In 2030, the typical number of flights in the European network in one day will be $18,000-33,000$ more than it is now. In growth terms, the traffic will on average increase by $2.2-3.5 \%$ a year. But this growth is not evenly distributed in time, across regions and flight flows. It is stronger in the beginning of the forecast period, slowing down in the later years (Table 1) (EUROCONTROL...2008).

There are several reasons for unequal distribution of growth.

These reasons are: increasing maturity of the market, pressure on higher ticket prices (e.g. due to rising oil and $\mathrm{CO}_{2}$ prices), and mainly in the later years the increasing congestion of the airports which are not able to serve the forecast demand.

Geographical distribution of the growth will be stronger in Eastern Europe where the air traffic market is relatively less mature and where there is a good potential for further growth as these States are catching up with the Western economies. As a result, Turkey and Poland will join the top 10 busiest States in Europe.

Table 1. Forecast growth in IFR movements to 2030

\begin{tabular}{|c|c|c|c|c|c|c|c|c|c|c|c|c|c|c|}
\hline \multirow{2}{*}{$\begin{array}{c}\text { Sce- } \\
\text { nario }\end{array}$} & \multicolumn{4}{|c|}{ IFR movements } & \multicolumn{5}{c|}{ Average Annual Growth, \% } & $\begin{array}{c}\text { AAGR, } \\
\%\end{array}$ & $\begin{array}{c}\text { Traffic } \\
\text { Multiple }\end{array}$ \\
\cline { 2 - 15 }$y$ & 2006 & 2007 & 2014 & 2020 & 2025 & 2030 & 2006 & 2007 & 2014 & $\begin{array}{r}2020 / \\
2016\end{array}$ & $\begin{array}{r}2025 / \\
2021\end{array}$ & $\begin{array}{r}2030 / \\
2026\end{array}$ & $\begin{array}{c}2030 / \\
2007\end{array}$ & $\begin{array}{c}2030 / \\
2007\end{array}$ \\
\hline A & - & - & 14,12 & 17,53 & 19,89 & 22,09 & - & - & 5,2 & 3,8 & 2,6 & 2,1 & 3.5 & 2.2 \\
\hline B & - & - & 12,93 & 15,55 & 17,76 & 19,55 & - & - & 3,9 & 3,1 & 2,7 & 1,9 & 3,0 & 2,0 \\
\hline C & 9,439 & 9,916 & 12,93 & 14,96 & 16,72 & 18,17 & 3,9 & 5,1 & 3,9 & 2,5 & 2,3 & 1,7 & 2,7 & 1,8 \\
\hline D & - & - & 11,77 & 13,46 & 15,06 & 16,51 & - & - & 2,5 & 2,2 & 2,3 & 1,8 & 2,2 & 1,7 \\
\hline
\end{tabular}


But it is not Germany who will add the most traffic to the network. The UK, Turkey and Spain are those that will see the biggest increase in the numbers of aircraft arriving to and departing from their airports (Fig. 1).

That is because the total numbers of flights in an airspace are the aggregate of domestic traffic within the States, arrivals from and departures to other European States or regions outside Europe, and flights crossing Europe without landing here.

It is the relative size of these flows and their speed of growth that generates the overall $2.2-3.5 \%$ growth per year.

In ESRA, it is the internal traffic which is the most important in terms of number of movements: almost $80 \%$ of all IFR movements were within ESRA in 2007.

This share will go down to a little below $70 \%$ by 2030, with ESRA internals growing by just $1.7-2.7 \%$ per year depending on the scenario, while the numbers of flights to and from ESRA grow by $3.8-5.8 \%$ (strong in particular for flights to/from the Former CIS Region and Far-East), and flights passing the ESRA airspace without landing here by 5.0-7.1\% (even though these are and will be relatively small in absolute numbers).

These also vary by State and especially the domestic flights within a State increase with different strength across ESRA region: in most of the Western Europe very little (e.g. Germany, Sweden, France), more in some of the big States in the East (e.g. Poland, Turkey). This again is due to the differences in maturity of the local markets, opportunity to use alternative means of transport such as high-speed rail and local geographical specificities.

\section{Risks to the Forecast}

The long-term forecast uses a set of four scenarios to give structure to the uncertainty about the future developments of air traffic industry. Though the scenarios vary in their specific mix of factors, a number of other elements can present additional risks for the forecast. Some of the main ones recognised for the LTF are listed below:

The forecast for traffic through each State's airspace is based on the simple assumption that the en route network remains as in 2007, as do the routes that aircraft follow on that network. In practice, there will be significant changes, particularly in the South East of Europe.

External events, such as pandemic, terrorist attacks, wars and natural disasters can all affect Air Traffic briefly, or for the long-term.

Tourism trends and economic growth are in fact cyclical, with peaks and troughs of.

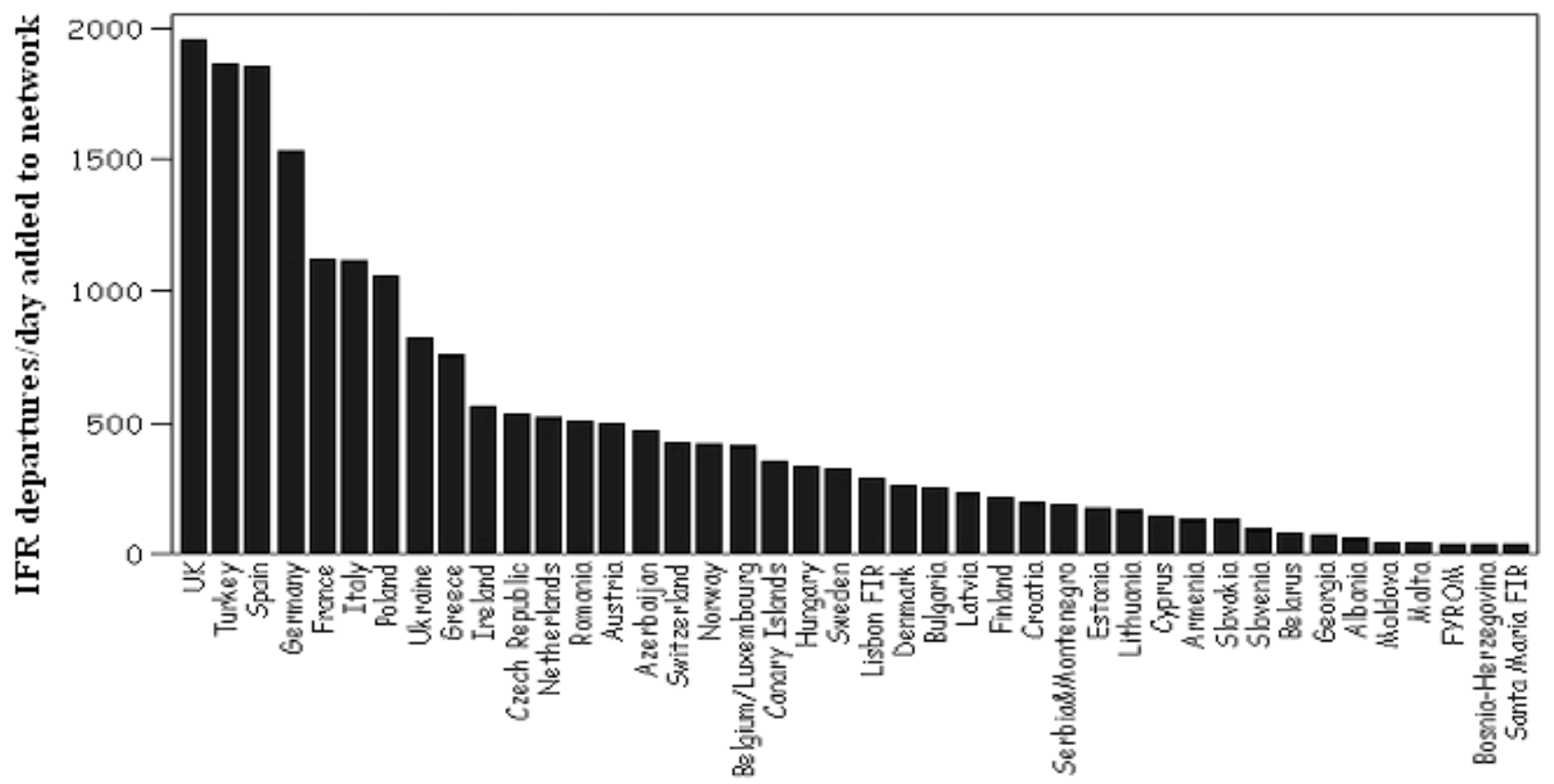

Traffic zone

Fig. 1. Traffic added to the network in 2030 (Scenario C: Regulation \& Growth) 
Many local changes are significant to particular airports, but less significant at the annual, State level for which this forecast is designed.

Airport plans for the developments of their infrastructure are included in the forecast as a condition for serving the increasing demand for flights. These plans may be delayed or may not realize for a number of reasons such as increasingly negative attitude of local communities to airfields' extensions, stricter environmental limits or simply lack of financial resources.

Low-cost carriers and business aviation have been the major contributors to growth in Europe in the recent years. New business models such as air-taxi service are on the verge of becoming drivers of the growth in the future. Current numbers of very light jets flying in Europe are still very low but theirintegration into the controlled airspace is under active discussion at Eurocontrol and elsewhere. The same is true for unmanned aircraft systems. Their strong potential for civil use makes it another segment with possible significant effect on future traffic growth. Supersonics or other "yet unknown" types of aircraft can have an effect which is difficult to estimate beforehand.

Climate change and other environment-related factors will certainly have an impact on the future of aviation not only within the next 20 years but also (and mainly) in the longer-term (Challenges...2008).

\section{More demand than capacity}

The forecast reviews the capacity of 138 major European airports, twice the number covered in the Challenges to Growth 2004 (Challenges...2004).

By 2030, these plan to increase their capacity in total by $41 \%$ (combining some new airports construction, new runways and other ground- and air-side infrastructure improvements). Nevertheless, the demand in 2030 will exceed the capacity by as much as 7 million flights in the high-growth scenario A: Global Growth. The congested airport system will need to operate very close to its limits, 14-39 airports in 2030 Europe will be operating very much like Heathrow does now.
Data for 138 airports including all of the 50 future major European airports (in terms of traffic in 2030) are used in the forecast to analyse the constraints of the airports. These major airports account for around $70 \%$ of the traffic in Europe meaning that the coverage is good enough to give a picture of the European airport system ability to serve the forecast demand. The survey results show that the airports plan for significant investments (Fig. 2).

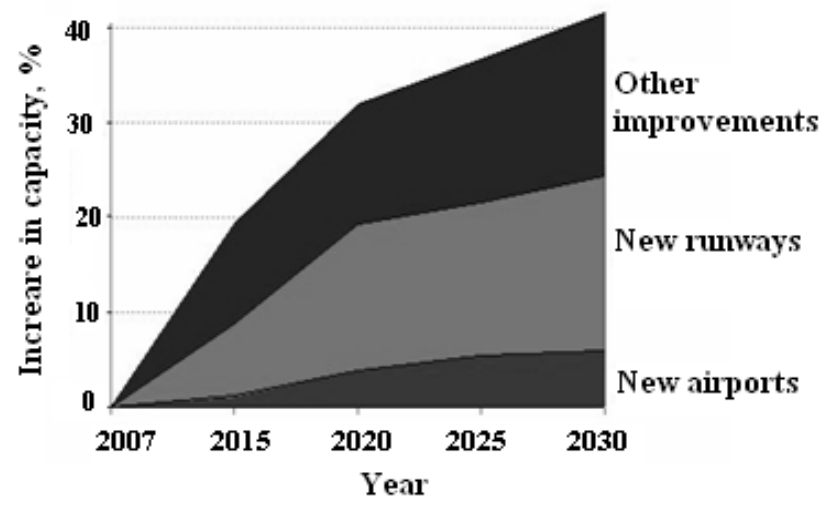

Fig. 2. Airports plan for significant investments in infrastructure improvement

The current plans are for at least (there could be more at airports not covered by the survey): 5 new major airports in Europe, new runways at 27 airports and other airside (taxiways, aprons etc.) and groundside (terminals etc.) improvements at another 79 airports. Only 27 airports reported no current plans to expand capacity. If these plans are carried out, the capacity of the system will increase by $41 \%$ by 2030 .

Although the capacity improvement as described above is quite substantial, the forecast results show that it will not be enough to serve the forecast demand.

There will be as many as 7.0 million flights (25\%) lost to airport capacity in the high-growth scenario A: Global Growth in 2030, which is the most challenging scenario in terms of the network capacity (Table 2 ).

Table 2. Excess of IFR flight demand over capacity (Movements Millions)

\begin{tabular}{|l|c|c|c|c|c|c|c|c|c|c|c|c|}
\hline \multirow{2}{*}{$\begin{array}{l}\text { LTF } \\
\text { year }\end{array}$} & \multicolumn{3}{|c|}{ Scenario A } & \multicolumn{3}{c|}{ Scenario B } & \multicolumn{3}{c|}{ Scenario C } & \multicolumn{3}{c|}{ Scenario D } \\
\cline { 2 - 16 } & 2020 & 2025 & 2030 & 2020 & 2025 & 2030 & 2020 & 2025 & 2030 & 2020 & 2025 & 2030 \\
\hline LTF08 & 1.3 & 3.7 & 7.0 & 0.5 & 1.6 & 3.2 & 0.3 & 0.9 & 2.3 & 0.2 & 0.4 & 0.8 \\
\hline LTF06 & 1.3 & 3.4 & - & 1.1 & 2.3 & - & 1.1 & 2.4 & - & 0.6 & 1.0 & - \\
\hline
\end{tabular}


Another effect of increasing demand at already congested airports is that these will need to operate at their full capacity several hours a day. The consequences for the ATM, delays, safety etc. are beyond the scope of this traffic forecast but should not be overlooked (Table 3).

Table 3. Airports running at capacity $8 \mathrm{hrs} /$ day in 2030

\begin{tabular}{|l|c|c|}
\hline \multicolumn{1}{|c|}{ Scenario } & $\begin{array}{c}\text { Number } \\
\text { Airports }\end{array}$ & $\begin{array}{c}\text { Flights } \\
\text { Affected, \% }\end{array}$ \\
\hline A. Global Growth & 39 & 70 \\
\hline B. Business as Usual & 25 & 60 \\
\hline C. Regulation and Growth & 19 & 50 \\
\hline D. Fragmenting World & 14 & 43 \\
\hline
\end{tabular}

Capacity of airports is naturally a local issue and the shortfall is not evenly distributed across Europe; in some regions it will be felt more strongly than in others. For example shows that airports in Turkey, the UK, France and Germany will loose the highest number of departures and arrivals in 2030 unless they further expedite their plans for infrastructure or operational improvements.

In practice, some of this unaccommodated demand can be satisfied by mitigation methods such as use of secondary airports or shifts to earlier morning or later evening hours.

\section{Airport growth}

Even with airport capacity restrictions, there will be an increasing number of large airports. In 2007, there was 1 airport in Europe with more than 250,000 departures: Paris/Charles de Gaulle.
In 2030, there will be between 7 and 15 airports of this size.

The top 10 European airports will handle 1.5-1.9 times more departures in 2030 than they did in 2007. But it is not only these biggest airports that will increase the traffic. Regional and secondary airports will also contribute to the forecasted growth and therefore the share of these biggest airports will remain roughly stable, between $22-24 \%$ in comparison with the current $23 \%$ share on total ESRA departures. Again, without the capacity constraints these airports would increase their share slightly to $23-26 \%$.

It is the combination of forecast growth in demand with the plans of the airports for capacity improvements and thus the ability to serve this increasing demand that determines the numbers of extra departures and arrivals handled by the airports. A number of airports in Eastern Europe will see significant growth by 2030 and are likely to outnumber (in terms of the departures) some of the current busiest airports.

\section{Importance of different growth factors}

The forecast model combines several factors with different effects in terms of strength and direction on the future traffic growth.

The "economy"-related factors play the dominant upward-pushing role, reduced mainly by the "market structure" and airport capacity. The various factors entering the forecast model have each different impact on the forecast future traffic growth in terms of both, strength and direction (Fig. 3).

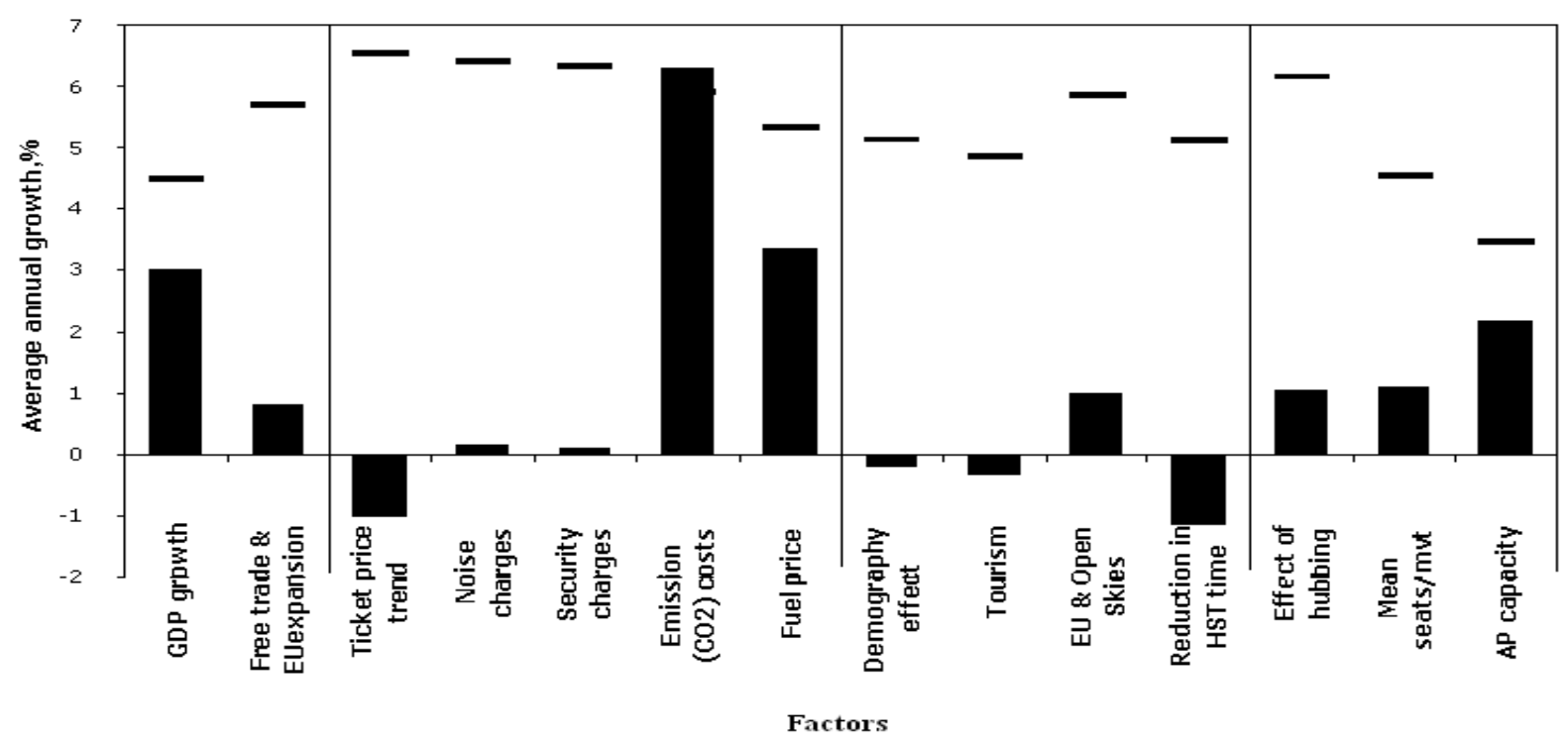

Fig. 3. Factors that lead to demand and forecast growth in traffic 
The figure presents a mix of the factors (bars in the graph) and shows schematically how these shift up or down the forecast growth in the number of passengers and movements (the dashes in the graph).

The graph provides a simplified step-by-step picture of the direction and relative size of the shifts, rather than the precise values. In reality, the forecast model is much more complex with possible interactions between the factors, irregular time patterns and supplementary network effects. It is the mix of these that produces the final forecast and the reason why neither of them can be treated separately as for simplicity suggested by the graph.

The long-term forecast method derives the growth in flights from the growth in passenger numbers. An increase in the disposable income and hence more money to spend on travel can be contradicted by equal or faster increase in Price of travel.

There are several contributors to the evolution of fares: continuously decreasing trend in the air-ticket price is lifted by noise and security charges added to the cost, additional expenses of the airlines related to $\mathrm{CO}_{2}$ emissions and oil price are passed onto the customers by increased fares. Naturally, changes in prices have inverse effect on the demand (higher price $\Rightarrow$ less demand) determined by the price elasticity.

Demand in terms of number of passengers is converted into the number of flights using an assumption about the Market Structure, that is the structure of the fleet and use of aircraft. The expected increase in the mean size of aircraft coupled with increasing load factors reduces the growth, so the growth in fights is significantly less than in passenger numbers.

The new long-term forecast has more variation then the previous one. The uncertainty about future developments is included in the scenario storylines.

\section{Conclusions}

The forecast is presented near 16.5-22.1 million IFR flight movements per year in the EUROCONTROL Statistical Reference Area (ESRA) in 2030, it is in 1.7-2.2 more times then in 2007. So the average growth of air traffic in European region will be near $2.3-3.5 \%$ per year.

There are plenty of potentials for further development of Air Traffic in Europe. But as the demand is not homogenous within different parts of European airspace the traffic growth can not be uniform,so it will be distributed unevenly in time and across regions. For example Poland and Turkey will be the busiest European countries.

Four scenarios are used in the long-term forecast in order to show the future possible developments in air traffic industry. These scenarios are: "A: Global Growth", "B: Business as Usual", "C: Regulation \& Growth" and "D: Fragmenting World".

But there are a number of risks which are not included in the forecast. These risks users should consider separately when planning for the future.

The forecast reviews the capacity of 138 major European airports, but the demand in 2030 will exceed the capacity by as much as 7 million flights in the high-growth scenario A: Global Growth. So the congested airport system will need to operate very close to its limits.

\section{References}

ICAO Doc 4444. Procedures for Air Navigation Services. Air Traffic Management. 22 November 2007. Montreal, Canada.

EUROCONTROL Long-Term Forecast: IFR Flight Movements 2008-2030. 19 November 2008. Brussels, Belgium.

Challenges of growth 2008: summary report, EUROCONTROL STATFOR. 2008. Brussels, Belgium.

Challenges of growth 2004 Report, ECACEUROCONTROL. December 2004. Brussels, Belgium. 
О.Є. Луппо ${ }^{1}$, О.В. Глушко ${ }^{2}$, Д.М. Долматова ${ }^{3}$. Аналіз повітряного руху в Європейському регіоні

Національний авіаційний університет, проспект Космонавта Комарова, 1, Київ, Україна, 03680

E-mails: ${ }^{1}$ luppo-ae@mail.ru; ${ }^{2}$ oks_glushko@mail.ru; ${ }^{3}$ dolmatova_darya@ukr.net

Розглянуто сценарії розвитку повітряного руху в майбутньому. Виконано довгостроковий прогноз розвитку повітряного руху в Європейському регіоні.

Ключові слова: довгостроковий прогноз розвитку повітряного руху, польоти за приладами, пропускна спроможність, сектори Свропейського регіону.

\section{А.Е. Луппо ${ }^{1}$, О.В. Глушко 2 Д.Н. Долматова ${ }^{3}$. Анализ воздушного движения в Европейском регионе}

Национальный авиационный университет, проспект Космонавта Комарова, 1, Киев, Украина, 03680

E-mails: ${ }^{1}$ luppo-ae@mail.ru; ${ }^{2}$ oks_glushko@mail.ru; ${ }^{3}$ dolmatova_darya@ukr.net

Рассмотрены возможные сценарии развития воздушного движения. Выполнен долгострочный прогноз развития воздушного движения в Европейском регионе.

Ключевые слова: долгострочный прогноз развития воздушного движения, полеты по приборам, пропускная способность, сектора Европейского региона.

Luppo Alexander (1958). Candidate of Pedagogy. Associate Professor.

Department of Air Navigation Systems, National Aviation University, Kyiv, Ukraine.

Education: Faculty of Flight Operation of Academy of Civil Aviation, Russia (1982).

Research area: imperfection of air traffic management, investigation of human factors in aviation, methods of perfection of professional level of air traffic controllers.

Publications: 55.

E-mail: luppo-ae@mail.ru

Hlushko Oksana (1993). Student of the National Aviation University, Kyiv, Ukraine.

Research area: optimization of systems and methods for imperfection of air traffic management.

Publications: 5.

E-mail: oks_glushko@mail.ru

Dolmatova Darya (1994). Student of the National Aviation University, Kyiv, Ukraine.

Research area: ATC Capacity Analyzer and imperfection.

Publications: 5.

E-mail: dolmatova_darya@ukr.net 